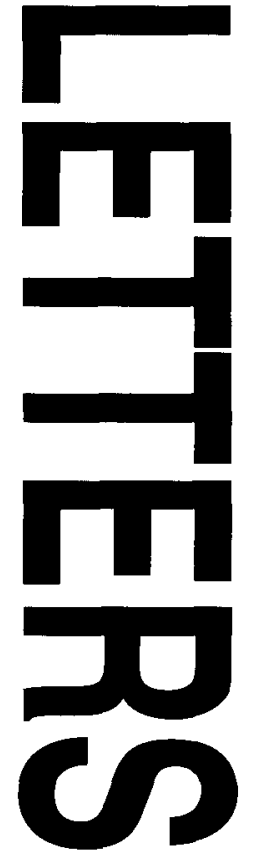

\section{Art libraries and recalled books}

Not long ago, two articles appeared in the library literature that I feel have particular importance for art librarianship, in the light of some recent developments. The articles are:

1. 'Promoting an Awareness of Retractions: The Louisiana State University Medical Centre in Shreveport Experience', by David Duggar et al, in Medical References Services Quarterly, Spring, 1995, p.1732.

2. 'Misconduct in Academic Research: Its Implications for the Service Quality Provided by University Libraries', by Peter Hernon and Ellen Altman, in The Journal of Academic Librarianship, January 1995, p.27-37.

In art history studies, at least three major studies, in the form of published books, have been recalled (the equivalent of 'retraction' of articles in scientific journals), and the circumstances of the recall differ in each case. It is not clear if art librarians, and students and scholars of art history, are aware of these recalls. The three works are:

1. Seidel, Max, Ambrogio Lorenzetti cronsita nuziale: alle origini della pittura di vita privata. Torino: Bollati Boringhieri, 1993.

2. Durbe, Dario, Due Pietre Ritrovate di Amedeo Modigliani. Sangiustino, 1984.

3. Ragionieri, Giovanna, Simone o non Simone. Firenze: La Casa Usher, 1985.

I think the following passages from the two articles are especially relevant for art librarians in this case:

. . . importance of retraction awareness and who is responsible for disseminating this knowledge'. (Duggar, p.17).

'... the unknowing citation of disputed data is a serious problem in scholarly endeavors ... researchers who are simply unaware of retractions may be misled . . . the notice of that report's retraction may remain undiscovered ... Retractions are aimed at preventing the perpetuation of erroneous ... data which can impede the scholarly process ...' (Duggar, p.18).

$\therefore$. what the libraries were doing to make their users cognizant of retracted literature'. (Duggar, p.18-19).

'. . acknowledgement of error issued by a publisher, editor, or author'. (Duggar, p.20).
'Making patrons aware of retracted publications is an important function of the library'. (Duggar, p.24).

'.. the trustworthiness of some material within library collections, even those cited in the scholarly literature, may be suspect . . . discredited works may remain within collections without any stigma attached to them . . . Is the library responsible ... for identifying discredited works? . . . alerting users that certain source material has been retracted ...' (Hernon, p.30).

As far as I can tell, each of the three books that have been retracted has different circumstances relating to the retraction (or recall, as the case may be). Apparently, Durbe's book on Modigliani was actually sequestered by court order, and bookstores were required to send back their copies. But by that time, many copies seemed to have already been sold. I learned recently that art libraries at Harvard, Yale, Princeton, the Getty Center, the Art Institute of Chicago, the Metropolitan Museum of Art and the National Gallery of Washington, are among libraries that own copies.

The Modigliani book was part of an exhibition that had the patronage of the President of Italy, and the government's Ministero per i Beni Culturali e Ambientali, and the book was published and edited by Durbe with the collaboration of the Soprintendenza. What's more, government agencies are responsible for the technical reports used as evidence by Durbe. And, as far as can be determined, this book is the only scholarly publication on the specific subject. Along this line, Fabio Bisogni (of University of Siena, and Harvard's I Tatti) stated that an attribution should remain, and should not be changed until a scholarly publication provides evidence which warrants a change of attribution. (Professor Mallory and I have discussed Bisogni's views in our article in Syracuse Scholar, Spring, 1991, 'The Guido Riccio Controversy and Resistance to Critical Thinking', p.52-53). It seems to me that the problem for art librarians, and students and scholars, in this case, is that the two sculptures in question are not rediscovered masterpieces by Modigliani, but the results of a practical joke by five students from Livorno, and of an artistic happening on the part of a dockworker and 
part-time painter from Livorno. Are librarians who have the book in their collection, and are students and scholars who might use the book for their studies, aware of the situation?

A review of the book by Seidel (Ambrogio Lorenzetti cronista . . .) rhetorically hinted that Seidel's work was the discovery of the century. Soon after, Seidel asked the publisher to recall the book from the bookstores (apparently because a student of Bellosi's at the University of Siena had evidence that the paintings were not by Ambrogio Lorenzetti, but by a Sienese painter of this century). The publisher sent telegrams to the bookstores, requesting them to return the book. It seems that there was no legal obligation in this case (in contrast to the Modigliani case) for the bookstores to return the book. Those who did, did so out of courtesy and professional decor. Not all the books were returned. I learned recently that the Getty library acquired a copy, and who knows how many other libraries have copies. Soon after requesting the publisher to recall the book, Seidel sent out a communication (to La Stampa, and perhaps to other organisations as well), stating that any review of the book, any citation of it, or reference to it would be a violation of intellectual property rights which protect unpublished works (as reported in La Stampa, December 15, 1993, p.18). And having stated that references to the book would violate rights that protect unpublished works, Seidel stated that copies in circulation were unauthorized (a contradictory situation if the work was in fact published). This effort to suppress discussion of the retraction of the book was rather successful, although some newspaper articles appeared in the wake of the recall, and Il Giornale dell'Arte also covered the story.

After the rather successful suppression of references to the book, and to its recall, took place, some rather unusual twists to the situation came about. It seems that there might be threats of possible legal action, on the part of the owner (or owners, as the case may be), against the former student of Professor Bellosi who has the alleged evidence that the paintings were not by Ambrogio Lorenzetti, if he writes that the paintings are from this century. What's more, in the September 1994 catalog Art Publications (Editoriale Umbra,
Foligno), Seidel's book is promoted and offered for sale (p.64, n.560), and is described as a study based on an important discovery (". . . un studio legato ad una importante scoperta'). It does not seem to me that a librarian reading this item would be aware that the book had been recalled, or that its author has claimed that the book has unpublished status. The publishers of Art Publications act as agents for prestigious publishers, including Thieme-Becker/ Vollmer (Leipzig), Klinkhardt \& Biermann (Munich), Arts and Antiques Edition (Munich), and Art Address Verlag (Frankfurt). Seidelo's book has again been included in the September 1996 Art Publications catalog.

In a footnote (n. 1) in the Mitteilungen des Kunsthistorischen Institues in Florenz (1994, Heft 1, p.41), Seidel writes what amounts to a retraction notice for the book. But he does not give the title of the book, nor the year of publication. In this case, if by chance librarians read the footnote, they might not necessarily associate the work in question with the book being promoted about the same time in Art Publications as a study based on an important discovery.

The book Simone o non Simone is a different story. A few years or so after it was published, a worker (perhaps an owner) at a bookstore in Siena mentioned to me that the book had been recalled, and asked if I knew of copies in circulation. I didn't give much attention to the situation. In fact, I felt that maybe I had misunderstood, and that the book was out of print and the bookstore was looking for copies for clients. Then, a short time ago, a student from Milano mentioned he was having difficulty getting access to the book. In the wake of this incident, the owner of a bookstore in Firenze acknowledged without a moment's hesitation - that there had been a recall. He did not know the reason, but made the suggestion it might have been economic (for a bulk sale to a discounter, etc.). The author, Giovanna Ragionieri, denies knowledge of a recall, and denies one took place, so in this case there was no author's retraction. The publishing house that is the successor to the original publisher was somewhat evasive to inquiries, but mentioned that some copies were in a storeroom near Milan. Recent attempts to gain access to these copies were

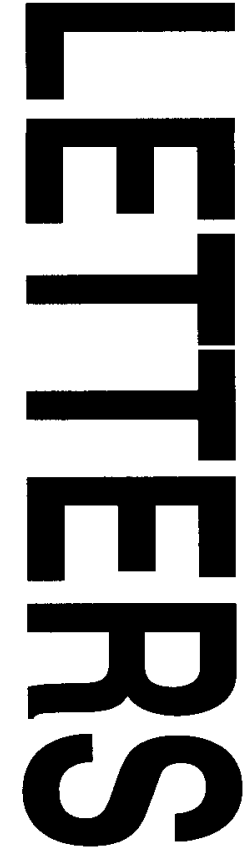




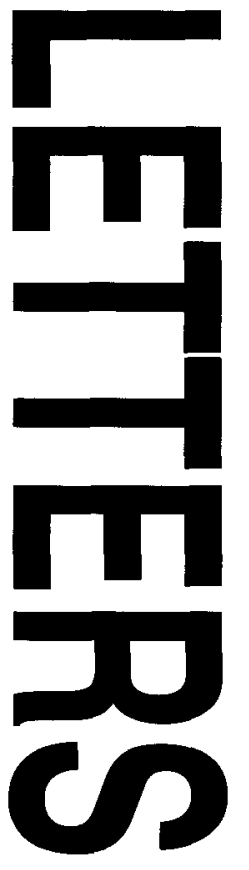

not successful. Thus, at this point, some uncertainty remains about the nature and the reason for this recall, and about whether it was a full recall or a partial one.

In any case, now that the subject of retractions is getting discussion and attention in the field of academic librarianship, I think art librarians' professional organisations should discuss the topic, including these three cases. Is there any mechanism in Art Libraries Journal, or in any other publications, which routinely alerts art librarians, and through them, art history scholars and students, to publications that have been recalled/retracted? For example, would students who read the Durbe Modigliani book in preparation for a term paper know that the book was recalled?

I would be interested in knowing the opinions of art librarians.

\section{Gordon Moran,}

Via delle Terme, 3,

Firenze,

Italy. 